\title{
NARODNOSTNO NEOPREDELJENO PREBIVALSTVO OB POPISIH I 99 I IN 2002 V SLOVENIJI
}

\author{
Peter Repolusk \\ Geografski inštitut Antona Melika, ZRC SAZU, Gosposka ulica I3, \\ 1000 Ljubljana, Slovenija \\ e-mail: peter.repolusk@zrc-sazu.si
}

Izvirni znanstveni članek

COBISS 1.01

\section{Izvleček}

Prispevek obravnava problematiko etničnega neopredeljevanja prebivalstva $\mathrm{v}$ popisnih podatkih za leti 1991 in 2002. Skupino sestavljajo etnično neopredeljeni ter statistični kategoriji neznano in »oseba ne želi odgovoriti na vprašanje«. Na podatek o etnični sestavi Slovenije v zadnjih dvajsetih letih je vplivalo predvsem spreminjanje števila oseb, za katere podatek o etničnem izvoru ni znan. V zadnjem desetletju se je zelo povečalo število oseb v kategoriji neznano.

Ključne besede: etnična sestava, etnično opredeljevanje, etnična identiteta, prebivalstvo Slovenije, popis prebivalstva

\section{ETHNICALLY UNDECLARED POPULATION IN SLOVENIAN POPULATION CENSUSES I99I AND 2002}

\begin{abstract}
The article deals with the ethnically undefined population within the territory of the Republic of Slovenia in the time of the population censuses 1991 and 2002. It consists of more statistical categories: the ethnically undeclared, the category unknown and the category of persons that decide not to answer to the question on ethnic heritage. In the last twenty years demographic changes concerning ethnically undefined groups had the most important role on the changes of the overall ethnic structure in the country. In last decade especially category unknown shows a substantial increase in number.
\end{abstract}

Key words: ethnic structure, ethnic declaring, ethnic identity, population of Slovenia, population census 


\section{UVOD}

Etnično (v preteklosti je bil pogosteje uporabljan termin narodnostno) neopredeljevanje je pojav v popisnih podatkih in metodologiji, ki navidez zakriva etnični razvoj slovenskega prebivalstva kot posledice mednarodnih migracij. Pravna možnost, ki prebivalstvu ob popisu omogoča, da se etnično ne opredeli, je bila podana leta 1971 in uveljavljena v popisni metodologiji nekdanje Jugoslavije istega leta (Šrcelj 2003). Kategoriji narodnostno neopredeljenih je statistična praksa nekdanje Jugoslavije in s tem tudi Slovenije dodala še dve kategoriji, ki sta se pogosteje pojavljali tako številčno kot tudi na širšem območju države - opredeljene kot Jugoslovane in regionalno opredeljene.

Metodologija slovenskega popisa prebivalstva je v prvem popisu v samostojni državi leta 2002 dodala še eno kategorijo narodnostno neopredeljenega prebivalstva-Bosance, ki je že v rezultatih prejšnjih popisov predstavljala večino regionalno opredeljenih. Dodana je bila tudi nova kategorija v skupini etnično opredeljenih - Bošnjaki. Za oživitev starega etničnega imena so se odločili bošnjaški intelektualci na kongresu v Sarajevu leta 1993 (Pašić 2005, 100), leta 1994 pa je ime sprejela tudi Ustava Federacije Bosne in Hercegovine. Metodologija je ohranila kategorijo Musliman (v smislu etnične pripadnosti).

Zelo pomembna metodološka sprememba je bila uvedba kategorije »oseba ne želi odgovoriti na vprašanje o etnični pripadnosti«. Pomembna metodološka razlika zadnjega popisa v primerjavi s predhodnimi je bila tudi ta, da je vsaka oseba (stara 14 let ali več) na vprašanje o etnični pripadnosti bodisi popisovalcu bodisi po pošti odgovarjala samostojno. V popisih do leta 1991 je podatek o etničnosti odsotnega člana gospodinjstva lahko posredovala polnoletna oseba iz istega gospodinjstva.

\section{SPREMEMBE ETNIČNE SESTAVE SLOVENIJE IN VLOGA ETNIČNEGA NEOPREDELJEVANJA}

Na razvoj in spremembe etnične sestave so tako v preteklosti kot danes vplivale migracije neslovenskega prebivalstva v Slovenijo in migracije Slovencev v tujino. Geografske posledice priseljevanj se odražajo predvsem $v$ mestnih in vedno bolj tudi v suburbaniziranih okoljih, kjer se vsaj lokalno vzpostavlja večetnični in večkulturni milje (visok delež prebivalstva, ki ni slovenske narodnosti, etnično heterogene družine, drsenje v etničnem opredeljevanju in občutenju posameznikov ipd). Najpomembnejša selitvena tokova, ki sta spremenila etnično podobo države, sta bila odselitev dela italijanskega in nemškega prebivalstva po drugi svetovni vojni ter migracije iz držav z območja nekdanje Jugoslavije, ki so bile najbolj intenzivne v obdobju 1975 do 1980 (Gosar 1993, Šircelj 2003, Josipovič 2005).

Podatki popisov prebivalstva dokaj dobro sledijo in prikazujejo spremembe v etnični sestavi do vključno leta 1981. Po tem letu začne naraščati število etnično neopredeljenega prebivalstva, v zadnjih obdobjih pa tudi prebivalstva, za katerega popisni podatek o etnični pripadnosti ni znan - kategorija neznano, v zadnjem popisu leta 2002 tudi »oseba ni želela odgovoriti na vprašanje o etnični pripadnosti (preglednica 1). 
Preglednica 1: Spremembe etnične sestave Slovenije v obdobju 1971 - 2002

Table 1: Changes of ethnic structure in Slovenia in the period 1971 - 2002

\begin{tabular}{|l|r|r|r|r|r|r|r|r|}
\hline & $\mathbf{1 9 7 1}$ & $\mathbf{1 9 8 1}$ & $\mathbf{1 9 9 1}$ & $\mathbf{2 0 0 2}$ & $\mathbf{1 9 7 1}$ & $\mathbf{1 9 8 1}$ & $\mathbf{1 9 9 1}$ & $\mathbf{2 0 0 2}$ \\
\hline & Število & Število & Število & Število & $\mathbf{\%}$ & $\mathbf{\%}$ & $\mathbf{\%}$ & $\mathbf{\%}$ \\
\hline Slovenci 1.578 .963 & 1.668 .623 & 1.689 .657 & 1.631 .363 & 94,0 & 90,8 & 88,3 & 83,1 \\
\hline Avtohtone manjšine $^{1}$ & 12.881 & 12.308 & 13.218 & 11.747 & 0,8 & 0,7 & 0,7 & 0,6 \\
\hline Pris. iz nekd. Jugoslavije $^{2}$ & 69.750 & 117.251 & 139.098 & 119.440 & 4,2 & 6,4 & 7,3 & 6,1 \\
\hline Drugi opredeljeni $^{2.499}$ & 2.498 & 3.049 & 4.432 & 0,1 & 0,1 & 0,2 & 0,2 \\
\hline Neopredeljeni & 3.012 & 2.853 & 8.716 & 12.085 & 0,2 & 0,2 & 0,5 & 0,6 \\
\hline Jugoslovani & 6.616 & 25.615 & 12.075 & 527 & 0,4 & 1,4 & 0,6 & 0,0 \\
\hline Regionalno opredeljeni & 2.652 & 3.932 & 5.187 & 9.529 & 0,2 & 0,2 & 0,3 & 0,5 \\
\hline Niso želeli odgovoriti & $\ldots$ & $\ldots$ & $\ldots$ & 48588 & & $\ldots$ & $\ldots$ & 2,5 \\
\hline Neznano & 2.678 & 5.301 & 42.355 & 12.6325 & 0,2 & 0,3 & 2,2 & 6,4 \\
\hline SKUPAJ & 1.679 .051 & 1.838 .381 & 1.913 .355 & 1.964 .036 & 100 & 100 & 100 & 100 \\
\hline
\end{tabular}

${ }^{1}$ Italijani, Madžari in Romi

${ }^{2}$ Albanci, Bošnjaki (Muslimani), Črnogorci, Hrvati, Makedonci in Srbi

Vir: Popisi prebivalstva, SURS

Če primerjamo podatke različnih popisov, je vloga etničnega neopredeljevanja v širšem pomenu besede (če vključimo še kategorijo neznano) razvidna v naslednjih pojavih:

- $\quad$ izrazit upad skupnega števila etnično opredeljenih, zlasti v zadnjem desetletju (padec z 87,8 na $83,1 \%$ );

- $\quad$ močno variiranje števila opredeljenih oseb posameznih etničnih skupin (npr. Italijani);

- $\quad$ izraziti padci (Jugoslovani) ali naraščanja (Romi) števila predvsem nekaterih etničnih ali neopredeljenih skupin;

- $\quad$ močno številčno upadanje opredeljenih za večino demografsko največjih etničnih skupin v zadnjem desetletju (Slovenci, Hrvati, Srbi);

- $\quad$ skokovit porast števila prebivalstva, za katere podatek o etnični pripadnosti ni znan, v zadnjem desetletju.

Vse navedene pojave je nemogoče utemeljevati z demografskimi razvojnimi trendi kot so npr. razlike ali dinamične spremembe rodnosti, povečana stopnja umrljivosti zaradi starostne sestave posameznih skupin, močna kratkočasovna preseljevanja pripadnikov posameznih etnij ipd. V javnosti in delu strokovnega tiska se je pojav naraščanja etničnega neopredeljevanje (skupaj z rastjo kategorije neznano) pogosto interpretira kot posledica etnično heterogenih zakonov ali izvenzakonskih skupnosti, katerih potomci naj bi se ne opredeljevali etnično oziroma naj bi prehajali v »nadetnično« opredeljevanje nacionalnega tipa, kot npr. Jugoslovani (zlasti do leta 1991). V obdobju 1975 do 1990 so etnično heterogeni zakoni predstavljali $15 \%$ od vseh in približno enako število potomcev. Dve tretjini od teh so bili zakoni slovenskega 
in neslovenskega partnerja, v katerih je bilo 85 do $90 \%$ otrok opredeljenih kot Slovenci (izračuni avtorja prispevka iz podatkov SURS). Število teh zakonov in razmeroma visoka stopnja potomcev, ki so bili etnično opredeljeni (na osnovi zgornjega podatka okrog $80 \%$ ) je daleč pod številčnim nivojem, s katerim bi lahko razložili pomembnejši del pojava etničnega neopredeljevanja.

V preglednici 1 so prikazane osnovne številčne spremembe etnične sestave Slovenije v zadnjih treh desetletjih. Praktično vse etnično opredeljene skupine so tako relativno kot absolutno številčno upadle. Najbolj intenziven padec števila opredeljenih v primerjavi s podatki za leto 1991 je značilen za Črnogorce, Hrvate, Italijane, Madžare in Srbe. Śtevilo opredeljenih kot Slovenci je upadlo za slabih 60.000. Pomemben številčni porast je značilen le za Rome, Albance in Bošnjake, če jih skupaj z etnično opredeljenimi Muslimani obravnavamo kot eno skupino. Pomembne spremembe so se zgodile tudi pri številčnosti narodnostno neopredeljenih skupin. Stalno narašča število opredeljenih v najožjem pomenu besede (neopredeljevanje na osnovi zakonske možnosti) ter regionalno opredeljenih, po številčni kulminaciji leta 1981 pa upada število opredeljenih kot Jugoslovani, katerih število se je leta 2002 zmanjšalo na le dvajsetino vrednosti iz leta 1981. Pri regionalno opredeljenih je potrebno poudariti, da jih sestavljata dve zelo različni skupini - opredeljeni kot Bosanci (8.062 tako opredeljenih leta 2002) in Istrani (1.234). Rast števila regionalno opredeljenih je pogojena predvsem z rastjo števila Bosancev, ki so bili ob popisu leta 1991 vključeni med regionalne opredelitve. Slovenska statistika Bosance obravnava kot ločeno etnično neopredeljeno kategorijo, v naši analizi pa jo zaradi kontinuitete in primerljivosti podatkov vključujemo med regionalno opredeljene.

Spremembe etničnega opredeljevanja po letu 1981, še posebej pa po letu 1991, je nemogoče razložiti zgolj z demografskimi spremembami znotraj statistično standardiziranih neopredeljenih skupin (neopredeljeni, Jugoslovani, regionalno opredeljeni). Razlago je mogoče iskati v skokovitem naraščanju števila oseb, za katere je podatek o etnični pripadnosti neznan in v vzpostavitvi nove kategorije za prebivalstvo, ki na popisno vprašanje ne želi odgovoriti. Če obe skupini obravnavamo skupaj, sta se med zadnjima popisoma številčno povečali za štirikrat, v skupnem prebivalstvu pa predstavljata $9 \%$ ali 174.913 oseb. Podatki analiz sprememb etničnega opredeljevanja posameznikov med popisoma 1991 in 2002 kažejo, da je $86 \%$ prebivalcev Slovenije ohranilo isto opredelitev, $6 \%$ se jih je etnično opredelilo, a drugače kot leta 1991 (najpogosteje so se kot Slovenci opredelili leta 1991 opredeljeni kot Hrvatje, Nemci, Italijani in Romi), 8 \% leta 1991 etnično opredeljenih pa v popisnih podatkih za leto 2002 sodi v kategoriji neznano in »ne želi odgovoriti« (Šircelj, 2003, 149 - 150).

\section{GEOGRAFSKE ZNAČILNOSTI NARODNOSTNEGA NEOPREDELJEVANJA}

Skupno je bilo ob popisu leta 2002 v Sloveniji 197.054 prebivalcev, za katere podatek o etnični pripadnosti ni znan. Več kot pol jih je živelo v Osrednjeslovenski, Podravski in Savinjski statistični regiji oziroma v urbanih središčih Ljubljana, Maribor, Celje in Velenje. Relativno najvišji delež v skupnem prebivalstvu regije so ob popisu 1991 predstavljali 
v Osrednjeslovenski in Obalno-kraški regiji, leta 2002 pa se je delež zelo povečal tudi v Podravski regiji in v Jugovzhodni Sloveniji (preglednica 2).

Preglednica 2: Etnično neopredeljeno prebivalstvo po statističnih regijah ${ }^{l}$

Table 2: Ethnically undeclared and undefined population by statistical region

\begin{tabular}{|c|c|c|c|c|c|c|c|}
\hline & $\begin{array}{r}\text { Neoprede } \\
\text { ljeni }^{2}\end{array}$ & Neznano & $\begin{array}{r}\text { Neoprede } \\
\text { ljeni }^{2} \\
\end{array}$ & $\begin{array}{l}\text { Niso želeli } \\
\text { odgovoriti }\end{array}$ & Neznano & $\begin{array}{r}\text { Neoprede } \\
\text { ljeni }\end{array}$ & Neznano \\
\hline & Delež 1991 & & Delež 2002 & & & \begin{tabular}{|r|} 
Indeks \\
spremembe \\
$2002 / 1991$
\end{tabular} & \\
\hline & $\%$ & $\%$ & $\%$ & $\%$ & $\%$ & index & index \\
\hline Gorenjska regija & 1,6 & 2,4 & 1,2 & 2,4 & 4,8 & 77,0 & 206,8 \\
\hline Goriška regija & 0,9 & 2,3 & 0,8 & 1,9 & 6,4 & 89,8 & 280,0 \\
\hline Jugovzhodna Slovenija & 1,0 & 2,1 & 0,8 & 2,4 & 7,3 & 79,2 & 346,1 \\
\hline Koroška regija & 0,5 & 1,9 & 0,5 & 2,1 & 5,4 & 92,7 & 283,0 \\
\hline Notranjsko-kraška regija & 1,7 & 2,5 & 1,5 & 2,2 & 5,8 & 90,1 & 232,5 \\
\hline Obalno-kraška regija & 4,1 & 4,6 & 3,2 & 3,1 & 8,3 & 81,4 & 185,8 \\
\hline Osrednjeslovenska regija & 1,9 & 3,5 & 1,7 & 2,7 & 6,7 & 92,7 & 196,2 \\
\hline Podravska regija & 0,8 & 2,5 & 0,5 & 2,7 & 7,3 & 63,8 & 286,2 \\
\hline Pomurska regija & 0,5 & 1,5 & 0,3 & 1,4 & 4,7 & 62,5 & 288,5 \\
\hline Savinjska regija & 0,9 & 2,6 & 0,8 & 2,6 & 6,2 & 89,2 & 236,9 \\
\hline Spodnjeposavska regija & 0,8 & 2,6 & 0,5 & 2,1 & 6,8 & 56,6 & 252,1 \\
\hline Zasavska regija & 1,9 & 2,4 & 1,6 & 2,6 & 5,6 & 81,5 & 221,6 \\
\hline SKUPAJ & 1,4 & 2,7 & 1,1 & 2,5 & 6,4 & 83,3 & 235,9 \\
\hline
\end{tabular}

${ }^{1}$ Podatek za leto 1991 vključuje zdomce

${ }^{2}$ Neoredeljeni, Jugoslovani in regionalno opredeljeni

Vir: Popisa prebivalstva 1991 in 2002, SURS

Poselitveni vzorec in rast števila vseh etnično nedefiniranih je do leta 1991 izrazito sledil siceršnjim demogeografskim razvojnim trendom v Sloveniji - delež je bil visok v urbanih središčih $\mathrm{z}$ dotokom prebivalstva in $\mathrm{v}$ regijah, $\mathrm{v}$ katere so se $\mathrm{v}$ preteklosti $\mathrm{v}$ večji meri usmerjali migracijski tokovi z območij nekdanje Jugoslavije. Za etnično neopredeljene skupine (neopredeljeni, regionalno opredeljeni in Jugoslovani) se je ta poselitveni vzorec ohranil tudi v letu 2002. Prav tako je geografska razporeditev neopredeljenih ostala zelo podobna tisti iz preteklih obdobij, le delež v skupnem prebivalstvu je v vseh regijah razmeroma enakomerno nazadoval, predvsem na račun zmanjševanja števila Jugoslovanov.

Prebivalstvo iz kategorije neznano je bilo že leta 1991 manj vezano na urbana območja, večja geografska razpršenost teh oseb pa se je v letu 2002 še povečala. Njihovo število se je med leti 1991 in 2002 najbolj povečalo prav v tistih regijah, kjer je bil njihov delež v skupnem prebivalstvu leta 1991 najnižji - v Goriški, Koroški, Podravski in Pomurski regiji ter v Jugovzhodni Sloveniji. Pojavnost kategorije neznano je tako razmeroma neodvisna od 
migracijskih in urbanih oziroma ruralnih značilnosti območja.

Podrobnejša analiza spreminjanja podatkov o etnični sestavi na nivoju upravnih enot ${ }^{1}$ nam podaja še naslednje statistično pomembne povezave med posameznimi segmenti etnične sestave:

- $\quad$ prostorski vzorec poselitve večjih etničnih skupin z območja nekdanje Jugoslavije (Albancev, Bošnjakov/Muslimanov, Črnogorcev, Hrvatov, Makedoncev in Srbov) leta 2002 je zelo podoben tistemu iz leta 1991; delež v skupnem prebivalstvu je statistično pomembno povezan $\mathrm{z}$ deleži urbanega prebivalstva, narodnostno neopredeljenih in $\mathrm{z}$ deležem tistih, ki niso želeli odgovoriti na vprašanje o etnični pripadnosti;

- $\quad$ upad relativnega števila opredeljenih kot Slovenci med letoma 1991 in 2002 je tesno povezan z rastjo števila oseb iz kategorije neznano in nekoliko manj s številčnostjo tistih, ki niso želeli odgovoriti na vprašanje;

- $\quad$ med bolj in manj urbaniziranimi upravnimi enotami leta 2002 ni statistično pomembnih razlik v deležih prebivalstva iz kategorije neznano, prebivalstvo iz kategorije »ne želi odgovoriti« pa je približno dvakrat pogostejše v mestih kot na podeželju.

Nekatere od zgornjih navedb potrjujejo tudi podatki iz preglednice 3. Deleži oseb posameznih etnično opredeljenih ali neopredeljenih skupin, ki žive v mestih, se v zadnjem desetletju niso bistveno spremenili. Izjema je le skupina neznano.

Preglednica 3: Odstotek etničnih skupin v mestnih in nemestnih naseljih

Table 3: Percentage of ethnic groups in urban and rural settlements

\begin{tabular}{|c|c|c|c|c|}
\hline & 1991 & 1991 & 2002 & 2002 \\
\hline & Mestna naselja & Nemestna naselja & Mestna naselja & Nemestna naselja \\
\hline & $\%$ & $\%$ & $\%$ & $\%$ \\
\hline Slovenci & 46,9 & 53,1 & 45,2 & 54,8 \\
\hline Avtohtone manjšine ${ }^{1}$ & 41,4 & 58,6 & 43,4 & 56,6 \\
\hline Pris. iz nekd. Jugos. ${ }^{2}$ & 82,5 & 17,5 & 81,7 & 18,3 \\
\hline Drugi opredeljeni & 74,2 & 25,8 & 70,5 & 29,5 \\
\hline Neopredeljeni ${ }^{3}$ & 78,9 & 21,1 & 77,9 & 22,1 \\
\hline Niso želeli odg. & $\ldots$ & $\ldots$ & 62,1 & 37,9 \\
\hline Neznano & 68,3 & 31,7 & 55,3 & 44,7 \\
\hline SKUPAJ & 50,5 & 49,5 & 48,9 & 51,1 \\
\hline
\end{tabular}

${ }^{1}$ Italijani, Madžari in Romi

${ }^{2}$ Albanci, Bošnjaki (Muslimani), Črnogorci, Hrvati, Makedonci, Srbi

${ }^{3}$ Neopredeljeni, Jugoslovani in regionalno opredeljeni

Vir: Popisa prebivalstva 1991 in 2002, SURS

\footnotetext{
${ }^{1}$ Natančnejši rezultati analize so dokumentirani pri avtorju prispevka
} 


\section{NEKATERE DEMOGRAFSKE ZNAČILNOSTI ETNIČNO NEOPREDELJENEGA PREBIVALSTVA}

Osnovne demografske razlike med pripadniki posameznih kategorij prebivalstva, za katere podatek o etničnosti ni znan ali so neopredeljeni, so podane v preglednici 4. Podatki o maternem jeziku, veroizpovedi in območju prvega bivanja (delež rojenih v Sloveniji) dokaj jasno razmejujejo tri skupine.

Kot Jugoslovani ali regionalno so opredeljeni predvsem priseljenci iz držav nekdanje Jugoslavije in njihovi potomci. "Srbohrvaščina« (bosanščina, črnogorščina, hrvaščina in srbščina) je materni jezik več kot sedemdesetim odstotkom prebivalstva. Po veroizpovedi med Jugoslovani prevladujejo pravoslavni, med regionalno opredeljenimi pa muslimani. Kot je bilo že rečeno, regionalno opredeljene sestavljata dve večji skupini, Bosanci in Istrani - slednji so številčno šestkrat šibkejši, po številnih demografskih znakih pa zelo različni od Bosancev - so pretežno katoličani, kot materni jezik je poleg hrvaščine in slovenščine pomembna še italijanščina, delež rojenih v Sloveniji je višji kot pri Bosancih in Jugoslovanih.

Preglednica 4: Nekatere jezikovne, verske in demografske značilnosti etnično neopredeljenega prebivalstva leta 2002

Table 4: Some linguistic, religious and demographic characteristics of ethnically undeclared population in 2002

\begin{tabular}{|c|c|c|c|c|c|}
\hline & Jugoslovani & $\begin{array}{l}\text { Regionalno } \\
\text { opredeljeni }\end{array}$ & Neopredeljeni & $\begin{array}{r}\text { Niso želeli } \\
\text { odgovarjati }\end{array}$ & Neznano \\
\hline & $\%$ & $\%$ & $\%$ & $\%$ & $\%$ \\
\hline Delež ${ }^{1}$ s slovenskim mat. jez. & 19,0 & 11,6 & 44,6 & 68,6 & 88,1 \\
\hline Delež $^{1}$ s srbohrvaškim ${ }^{2}$ mat. jez. & 70,5 & 81,6 & 50,3 & 28,0 & 9,9 \\
\hline Delež $\check{z}^{3}$ katoličanov & 14,3 & 16,6 & 43,1 & 54,3 & 73,9 \\
\hline Delež ${ }^{3}$ pravoslavnih & 63,0 & 14,5 & 32,6 & 26,3 & 15,5 \\
\hline Delež $\check{z}^{3}$ muslimanov & 20,8 & 68,3 & 18,5 & 17,1 & 8,2 \\
\hline Delež rojenih v Sloveniji & 32,8 & 30,2 & 57,1 & 74,0 & 87,7 \\
\hline Delež starih 0 do 14 let & 4,6 & 13,6 & 18,0 & 17,3 & 11,7 \\
\hline Delež starih 65 in več let & 11,2 & 6,6 & 5,4 & 9,4 & 8,7 \\
\hline
\end{tabular}

${ }^{1}$ Od jezikovno opredeljenih

${ }^{2}$ Bosanski, črnogorski, hrvaški, srbski, hrvaško-srbski, srbohrvaški

${ }^{3}$ Od versko opredeljenih

Vir: Popis prebivalstva 2002, SURS

Nasprotno kot pri prvi skupini pri kategorijah ne želi odgovoriti in neznano delež oseb s slovenskim maternim jezikom presega dve tretjini, v skupini neznano je slovenščino kot materni jezik opredelilo skoraj devet desetin vprašanih (od jezikovno opredeljenih). Podobno med versko opredeljenimi izrazito prevladujejo katoličani, delež v Sloveniji rojenih je 
približno dva in pol krat višji kot pri Jugoslovanih in regionalno opredeljenih. Za skupino neznano podatek o veroizpovedi temelji na zelo majhnem številu versko opredeljenih - za veliko večino tudi podatek o veroizpovedi sodi v kategorijo neznano.

Neopredeljeni v najožjem pomenu besede (na osnovi možnosti, ki jo opredeljuje zakonodaja) so $\mathrm{v}$ vseh pogledih vmesna skupina. Skupaj s kategorijo tistih, ki na vprašanje o etničnosti niso želeli odgovoriti, je po etničnih značilnostih in izvoru prebivalstva verjetno najbolj heterogena.

Primerjava demografskih značilnosti etnično neopredeljenih iz leta 2002 z rezultati analiz za leto 1991 (Repolusk, 1999) kaže naslednje osnovne razlike: pri Jugoslovanih, regionalno opredeljenih in neopredeljenih $\mathrm{v}$ ožjem pomenu besede je v primerjavi z letom 1991 upadel delež rojenih $v$ Sloveniji in delež oseb s slovenskim maternim jezikom. $V$ vseh treh kategorijah se je zelo znižal delež najmlajših ( 0 do 14 let), s približno 27 na $16 \%$. Slednje je mogoče razložiti s staranjem tako opredeljene populacije, deloma pa tudi s tem, da so se mladi etnično opredelili drugače, kot so jih leta 1991 opredelili starši. V splošnem velja, da v neopredeljenih skupinah v primerjavi s celotnim prebivalstvom prevladuje prebivalstvo srednje generacije. Za osebe iz kategorije neznano velja, da je skupna v primerjavi s popisom 1991 starejša, manj zgoščena na urbaniziranih območjih ter da je zelo upadel delež preseljenih v Slovenijo.

\section{SKLEP}

Spremembe popisnih podatkov o etnični sestavi po letu 1981 izrazito kroji rastoč delež prebivalstva, ki se etnično ne opredeli, ne želi odgovoriti na vprašanje ali podatek ostaja neznan. Tako npr. na osnovi podatkov lahko upravičeno sklepamo, da se je delež Srbov in Bošnjakov/ Muslimanov med leti 1981 in 1991 povečal na račun padca opredeljenih kot Jugoslovani, demografsko utemeljena rast števila Slovencev pa upočasnila na račun v letu 1991 prvič zelo povečanega števila kategorije neznano. Enako lahko sklepamo, da je številčni upad skoraj vseh etnično opredeljenih skupin leta 2002 posledica skokovitega porasta kategorije neznano in v metodologiji popisa na novo vpeljane kategorije »ne želi odgovoriti«. Absolutno največja je sprememba števila Slovencev, ki je v veliki posledica upada tako opredeljenih predvsem na podeželskih in nizko urbaniziranih območjih vzhodne in jugovzhodne Slovenije, ki so bila v preteklosti etnično zelo homogena. Menimo, da je spreminjanje etničnega opredeljevanja pri prebivalstvu predvsem odziv na zelo spreminjajoče se pogoje družbenega življenja, poglavitni skupini vzrokov pa sta:

- $\quad$ spremembe v metodologiji popisa prebivalstva;

- $\quad$ zelo različni družbeni in geopolitični pogoji, v katerih so zadnji popisi potekali

(relativna stabilnost okrog leta 1981, izrazito krizno obdobje ob razpadu nekdanje

Jugoslavije okrog leta 1991 in močno spremenjeno življenje v samostojni Sloveniji v

času zadnjega popisa).

Podatki o etnični sestavi prebivalstva zaradi rastočega števila neopredeljenih in kategorije neznano ne izgubljajo analitične vrednosti, potrebno pa bi jih bilo vrednotiti v pogojih spreminjanja vsebine in vloge etnične identitete v globalni in postmoderni družbi. 


\section{Literatura in viri}

Gosar, A. 1993: Nationalities of Slovenia - changing ethnic structures in Central Europe. GeoJournal, vol. 30, no. 3 .

Josipovič, D. 2005: Demogeografski učinki imigracije v Sloveniji po II. svetovni vojni (v perspektivi dejavnikov migracij in sprememb rodnostnega obnašanja). Doktorsko delo. Univerza v Ljubljani, Filozofska fakulteta, Oddelek za geografijo.

Pašić, A. 2005: Islam in Muslimani v Sloveniji. Zbirka Žepna knjiga, Učila International. Tržič.

Popis prebivalstva, gospodinjstev, stanovanj in kmečkih gospodarstev v Republiki Sloveniji v letu 1991. SURS.

Popis prebivalstva, gospodinjstev, stanovanj v Republiki Sloveniji v letu 2002. SURS.

Repolusk, P. 1999: Ethnically undefined population in Slovenia population census in 1991. V: Koter, M. (ur.), Heffner, K. (ur.). Multicultural regions and cities, (Region and regionalism, No. 4). Łodź-Opole: Universiti of Ĺódź, Department of political geography and regional studies.

Šircelj, M. 2003: Verska, jezikovna in narodna sestava prebivalstva Slovenije. Popisi 1921 - 2002. Posebne publikacije 2. Statistični urad Republike Slovenije. Ljubljana.

\section{ETHNICALLY UNDECLARED POPULATION IN SLOVENIAN POPULATION CENSUSES I99I AND 2002}

\section{Summary}

The analysis of the ethnically undefined and undeclared population in Slovenian Population Censuses in 1991 and 2002 are including several statistical categories: declared as Yugoslavs, regionally declared, ethnically undeclared regarding the option provided by Constitution, the category unknown and the category of persons that decide not to answer to the question on ethnic heritage.

Ethnic structure of Slovenia is a result of past and present migrations. In the first decade after the World War II there was a significant decline in the number of the autochthonous Italian and German population. The ethnic structure started to change more radically due to a strong affluence of economic immigrants from all parts of Yugoslavia, especially in the period 1975 - 1985. The majority of immigrants settled in cities and suburbanised areas. In regions and settlements with more diverse ethnic structure emerged growing number of persons, that were ethnically undeclared already at the time of Population Census in 1981. After that period and especially in last decade Census data are showing rapid increase of population in the category unknown ethnicity. The basic tendencies in the changing process of ethnic structure in the last decade can be grouped into conclusions as follows:

- $\quad$ permanent increase in number of ethnically undeclared and declared regionally (consisting predominantly of Bosnians and Istrians);

- $\quad$ strong decline in number of persons declared as Yugoslavs; 
- decline in number of the majority of larger ethnic groups (Slovenians, Croats, Serbs, Hungarians, Montenegrins, Italians);

- $\quad$ increase in number of some ethnic groups - Albanians, Bosniaks and Roma;

- $\quad$ strong increase in number of the category ethnicity unknown; together with the category of persons that decide not to answer to the question on ethnic heritage the number of persons in the period $1991-2002$ have enlarged for four times.

Radical changes in ethnic structure can not be explained thru demographic processes like fertility and mortality rates or net migration. Decline of ethnically declared groups is a direct result of growing number of individuals in the category unknown. Additional explanations can be found in the results of analyses showing that in 2002 about $7 \%$ of Slovenian inhabitants declared themselves ethnically but in favour of some other group than in the year 1991.

Linguistic, religious and migration statistics are showing that declared as Yugoslavs and regionally declared consist predominantly of immigrants from former Yugoslavia and their descendents. On the other hand demographic, religious and linguistic structure of group unknown ethnicity is very similar to that of Slovenians. Groups undeclared and persons that decide not to answer are intermediate and share characteristics of both previously described groups. 